\title{
Carcass Traits and Meat Composition of Hansli $\times$ CSML bird under Intensive and Semi-intensive Rearing Systems
}

\author{
Abhijeet Champati ${ }^{1 *}$, Lipismita Samal ${ }^{1}$, Nrusingha Charana Behura ${ }^{1}$, Prasad Kumar Pati ${ }^{2}$, \\ Soubhagya Muduli ${ }^{1}$ and Haresh Kashinathrao Popalghat ${ }^{1}$ \\ ${ }^{1}$ Post Graduate Department of Poultry Science, College of Veterinary Science and Animal Husbandry, Odisha University of \\ Agriculture and Technology, Bhubaneswar, Odisha, INDIA \\ ${ }^{2}$ Department of Livestock Products and Technology, College of Veterinary Science and Animal Husbandry, Odisha University of \\ Agriculture and Technology, Bhubaneswar, Odisha, INDIA \\ "Corresponding author: A Champati; E-mail: sonu4.live@rediffmail.com
}

Received: 25 June, 2020

Revised: 08 Nov., 2020

Accepted: 29 Nov., 2020

\begin{abstract}
This study was conducted to compare the carcass traits and meat composition of Hansli $\times$ CSML crossbred chickens reared under intensive and semi-intensive rearing systems. At $18^{\text {th }}$ week of age, three birds per sex from each rearing system were slaughtered. Carcasses were dissected into primal cuts. Breast and thigh meat samples were used for chemical analysis. The dressing and eviscerated yield \% of birds under intensive system was significantly $(\mathrm{P} \leq 0.05)$ more than under semi-intensive system. The thigh and drumstick yield $\%$ of semi-intensive bird was significantly $(\mathrm{P} \leq 0.05)$ higher than that of intensive bird. The carcass traits of males were significantly $(\mathrm{P} \leq 0.05)$ higher than that of females. The results from the meat analysis recorded a higher protein and lower fat content in breast and thigh meat of birds under semi-intensive system. The meat samples of female birds had a higher fat content and somewhat lower protein content as compared to males.
\end{abstract}

\section{HIGHLIGHTS}

(0 Effects of different rearing systems and sex on the carcass traits and chemical composition of meat in poultry birds.

0 Birds reared under semi-intensive system could be of higher nutritional and economic advantage to the customers.

Keywords: Carcass, Intensive, Meat composition, Semi-intensive, Sex

Poultry production strategies should be adequate to meet the criteria regarding the production of biologically valuable food, animal welfare and rationalization of the production process. Bearing in mind the interests of consumer and the slaughter industry, chickens should have high slaughter yields, desirable carcass conformation, and good aesthetic, sensory and nutritional characteristics. Therefore, the chemical composition of muscle tissue of major primal cuts is a chief element of chicken meat quality (Suchy et al., 2002). Many factors affect growth and performance of birds, including genotype, age, sex, diet, environment, rearing system and exercise (Gordon and Charles, 2002). The effect of rearing system on growth, carcass yield and meat composition of chicken has been studied by a number of authors (Ristić, 2003; Dou et al., 2009). It has been observed that outdoor rearing systems (free-range, semi-intensive) reduce stress while increasing comfort and bird welfare, thus enhancing the flavour (taste and aroma) of products, as compared to conventionally (intensive) raised birds. A positive effect of rearing system on certain meat quality traits (breast and thigh yields, improved sensory quality) was reported by Castellini et al. (2002), Fanatico et al. (2005) and Dou et al. (2009). The authors have also observed a reduced

How to cite this article: Champati, A., Samal, L., Behura, NC., Pati, P.K., Muduli, S. and Popalghat, H.K. (2020). Carcass traits and meat composition of Hansli $\times$ CSML bird under intensive and semi-intensive rearing systems. J. Anim. Res., 10(6): 1051-1055.

Source of Support: None; Conflict of Interest: None

(क) 
content of fat (abdominal fat in particular) in outdoor chickens as attributable to more intensive locomotor activity. Given the above, the objective of this study was to evaluate the effect of rearing systems and sex on the major meat quality traits (percent yield of primal cuts and chemical composition of muscle tissue) in Hansli $\times$ CSML (Coloured Synthetic Male Line) birds.

\section{MATERIALS AND METHODS}

The experiment was conducted at the poultry farm of the AICRP on "Poultry Breeding", College of Veterinary Science and Animal Husbandry, Odisha University of Agriculture and Technology, Bhubaneswar. Before the start of the experiment, the animal studies were approved by the institutional ethics committee- IAEC, C.V.Sc \& A.H., OUAT, Bhubaneswar, Odisha. (Regd. No.433CPCSEA/ CVS/2007) and was conducted in accordance with the ethics standards as applicable under international, national and/or institutional guidelines.

\section{Experimental birds, feeding and management}

Adult Hansli males and Colour synthetic male line (CSML) females were bred to develop the Hansli x CSML (F1) progenies. One hundred eighty six (186) day old chicks of the F1 cross were randomly collected and raised in cages up to six week of age. All the chicks were maintained on similar feeding $(20 \% \mathrm{CP}$ and $2866 \mathrm{kcal} / \mathrm{kg} \mathrm{ME}$, ad libitum feeding) and management conditions. On completion of $6^{\text {th }}$ week, birds were randomly divided into two treatments (intensive system and semi-intensive system) and each treatment was represented by three replications containing 30 birds each. A floor space of $2.5 \mathrm{ft}^{2} /$ bird was provided in deep litter under intensive system while a coop floor space@2.5 $\mathrm{ft}^{2} /$ bird and pasture run space @ $15 \mathrm{ft}^{2} /$ bird was provided under semi-intensive system. Cynodon dactylon (Doob grass), Talinum triangulare (water leaf) and Tridax procumbens (Bisalyakarani) were the major vegetation in the pasture space which was securely fenced around to avoid predatory attacks. Birds under intensive system were fed ad libitum diet containing $18 \% \mathrm{CP}$ and $2822 \mathrm{kcal} / \mathrm{kg}$ ME (AOAC, 1995) while birds under semiintensive system were allowed to scavenge in pasture and supplemented with $50 \%$ of the amount of feed allocated to birds under intensive system.

\section{Slaughtering procedure and carcass traits}

Three male and three female birds were randomly selected from each treatment group for evaluation of carcass traits at $18^{\text {th }}$ week of age. The selected birds were isolated from the flock and were off-fed overnight but were provided with adlibitum water. In the morning, prior to slaughter, birds were weighed individually and live weight was recorded. The birds were slaughtered by severing the jugular vein and carotid artery below the left ear by a single incision and allowed to bleed for a period of three minutes by holding the bird's head down. After complete bleeding and cessation of movement, the carcass weight was recorded. The carcass was then scalded at $55-58^{\circ} \mathrm{C}$ for 90 seconds and defeathered. Left over pin feathers were removed manually with a pinning knife. A transverse incision at the abdomen of the carcass between the keel and vent was made and then a circular incision around the vent was made to cut open the abdominal cavity for evisceration. The inedible offals like wind pipe, oesophagus, crop and all portions of the intestinal tract, vent, spleen, lungs, epicardium, ovaries and testis and gall bladder were removed. The giblet weight [liver, gizzard (without mucous membrane) and the heart (after removal of blood clot and pericardium)] and primal cut-up parts (drumsticks, thighs, breast, wings, back and neck) weights were recorded. Cut-up parts yield \% was calculated based on eviscerated weight. Percentage yield of giblet was calculated based on dressed carcass weight. Dressing percentage was calculated as the ratio between carcass weight and pre-slaughter live weight.

\section{Chemical composition of Thigh and Breast Meat}

Meat samples were collected from thigh and breast muscles, minced, mixed and then random samples were taken for further chemical analysis. Six replicates were done for each parameter. Protein and fat contents were determined according to AOAC (1990).

\section{Data Analysis}

Data collected in the above experiment were statistically analyzed using SPSS (V 25.0) computer package. Data were subjected to t-test to know the significance level of different parameters. The differences between means were declared significant at $\mathrm{P} \leq 0.05$. 


\section{RESULTS AND DISCUSSION}

\section{Effect of sex and rearing systems on carcass traits}

The effect of sex and rearing systems on carcass traits of Hansli $\times$ CSML birds is presented in Table 1 and Table 2, respectively. Male birds recorded a significantly $(\mathrm{P} \leq 0.05)$ higher carcass yield $\%$, primal cut yield $\%$ and giblet yield $\%$ than female birds as the male birds were significantly heavier. A number of studies (Melo et al., 1996; Ozkan et al., 1997) showed that carcass weight, primal cut parts weight and giblet weight was significantly higher in male chickens than in females, due to large differences in body weight. As for the effect of rearing systems, birds under intensive system had a significantly $(\mathrm{P} \leq 0.05)$ higher live weight and carcass yield \%(dressing and eviscerated yield $\%)$ as compared to those under semi-intensive system. The present findings were in agreement with findings reported by previous workers (Doley et al., 2009; Kalio et al., 2012; Kuźniacka et al., 2014 and Sanka and Mbaga, 2014) that birds managed under the intensive systems showed superior average live weight as compared to those managed in the semi-intensive system. This may be due to the fact that birds under intensive system had adequate feed availability and in turn higher growth rate than birds under semi-intensive system. Thigh and drumstick yield $\%$ of Hansli $\times$ CSML birds under semi-intensive system was significantly $(\mathrm{P} \leq 0.05)$ higher than that of intensive system, whereas the breast and back yield \% were higher for intensive system. The present findings corroborated with the findings of Castellini et al. (2002), Kalio et al. (2012) and Sanka and Mbaga (2014) who reported the breast and back \% of birds in confinement was higher than that of semi-intensive system while for thigh and drumstick the reverse was true. No significant difference $(\mathrm{P}>0.05)$ was found in the giblet yield $\%$ between the two systems, which was in agreement with the findings of many authors (Doley et al., 2009; Kuźniacka et al., 2014; Bartlett et al., 2015; Kaya and Yildirim, 2018). As the birds under intensive system attained a higher live body weight than that of birds under semi-intensive system, the eviscerated, dressed, primal cut parts and giblet weight were higher for birds under intensive system. The higher drumstick, thigh, neck and wings yield \% of birds under semi-intensive system may be due to better muscle mass growth, owing to their scavenging activities in pasture.
Table 1: Effect of sex on carcass traits of Hansli $\times$ CSML birds

\begin{tabular}{|c|c|c|c|c|}
\hline \multirow{2}{*}{ Attributes } & \multicolumn{2}{|c|}{ Sex } & \multirow{2}{*}{ SEM } & \multirow{2}{*}{ P-value } \\
\hline & Male & Female & & \\
\hline Live weight (g) & $2428.33^{\mathrm{a}}$ & $1926.83^{b}$ & 170.06 & 0.000 \\
\hline \#Dressing yield\% & $74.69^{\mathrm{a}}$ & $72.87^{b}$ & 0.49 & 0.000 \\
\hline \#Eviscerated yield \% & $71.08^{\mathrm{a}}$ & $70.43^{b}$ & 0.39 & 0.001 \\
\hline${ }^{\alpha}$ Neck yield $\%$ & $8.89^{\mathrm{a}}$ & $8.43^{\mathrm{b}}$ & 0.05 & 0.000 \\
\hline${ }^{\alpha}$ Wings yield \% & $12.83^{\mathrm{a}}$ & $12.27^{b}$ & 0.09 & 0.000 \\
\hline${ }^{\alpha}$ Back yield \% & $20.04^{\mathrm{a}}$ & $19.60^{\mathrm{b}}$ & 0.15 & 0.003 \\
\hline${ }^{\alpha}$ Breast yield \% & $24.11^{\mathrm{a}}$ & $23.81^{b}$ & 0.09 & 0.015 \\
\hline${ }^{\alpha}$ Thigh yield \% & $18.07^{\mathrm{a}}$ & $17.60^{\mathrm{b}}$ & 0.15 & 0.002 \\
\hline${ }^{\alpha}$ Drumstick yield \% & $15.75^{\mathrm{a}}$ & $15.10^{\mathrm{b}}$ & 0.228 & 0.001 \\
\hline ^Giblet yield \% & $4.83^{\mathrm{a}}$ & $3.35^{\mathrm{b}}$ & 0.131 & 0.000 \\
\hline
\end{tabular}

a,b Mean with different superscripts in a row differ significantly $(\mathrm{P} \leq 0.05)$

\#Percentage yield of live weight; ${ }^{\alpha}$ Percentage yield of eviscerated weight; ^Percentage yield of dressed weight; $\mathrm{N}=6$ (3 male and 3 female per system)

Table 2: Effect of rearing systems on carcass traits of Hansli $\times$ CSML birds

\begin{tabular}{|c|c|c|c|c|}
\hline \multirow[b]{2}{*}{ Attributes } & \multicolumn{2}{|c|}{ Rearing system } & \multirow[b]{2}{*}{ SEM } & \multirow[b]{2}{*}{ P-value } \\
\hline & Intensive & $\begin{array}{l}\text { Semi- } \\
\text { intensive }\end{array}$ & & \\
\hline Live weight (g) & $2553.83^{\mathrm{a}}$ & $1801.33^{b}$ & 114.82 & 0.001 \\
\hline \#Dressing yield \% & $74.79^{\mathrm{a}}$ & $72.78^{b}$ & 0.45 & 0.010 \\
\hline${ }^{\#}$ Eviscerated yield \% & $71.58^{\mathrm{a}}$ & $69.94^{\mathrm{b}}$ & 0.20 & 0.000 \\
\hline${ }^{\alpha}$ Neck yield $\%$ & 8.61 & 8.70 & 0.11 & 0.572 \\
\hline${ }^{\alpha}$ Wings yield \% & 12.47 & 12.63 & 0.15 & 0.459 \\
\hline${ }^{\alpha}$ Back yield \% & $20.12^{\mathrm{a}}$ & $19.52^{b}$ & 0.13 & 0.008 \\
\hline${ }^{\alpha}$ Breast yield \% & 24.05 & 23.87 & 0.10 & 0.251 \\
\hline${ }^{\alpha}$ Thigh yield \% & $17.53^{\mathrm{b}}$ & $18.14^{\mathrm{a}}$ & 0.12 & 0.006 \\
\hline${ }^{\alpha}$ Drumstick yield \% & $14.98^{\mathrm{b}}$ & $15.87^{\mathrm{a}}$ & 0.18 & 0.007 \\
\hline Giblet yield \% & 4.28 & 3.90 & 0.35 & 0.456 \\
\hline
\end{tabular}

${ }^{a, b}$ Mean with different superscripts in a row differ significantly $(\mathrm{P} \leq 0.05)$

"Percentage yield of live weight; ${ }^{\alpha}$ Percentage yield of eviscerated weight; ${ }^{~ P e r c e n t a g e ~ y i e l d ~ o f ~ d r e s s e d ~ w e i g h t ; ~} \mathrm{~N}=6$ ( 3 male and 3 female per system)

Effect of sex and rearing systems on chemical composition of thigh and breast meat

The poultry meat quality attributes may be affected by several factors such as genotype, stocking density, rearing 
condition, diet, exercise, pasture intake, temperature, age at slaughter and motor activity of the birds that impact on muscle metabolism as well as on chemical composition (Gordon and Charles, 2002). The effect of sex and rearing systems on chemical composition of thigh and breast meat of Hansli $\times$ CSML birds is presented in Table 3 and Table 4 , respectively.

Table 3: Effect of sex on chemical composition of thigh and breast meat of Hansli $\times$ CSML birds

\begin{tabular}{|c|c|c|c|c|}
\hline \multirow{3}{*}{ Attributes } & \multicolumn{4}{|c|}{ Thigh Meat } \\
\hline & \multicolumn{2}{|c|}{ Sex } & \multirow[b]{2}{*}{ SEM } & \multirow[b]{2}{*}{ P-value } \\
\hline & Male & Female & & \\
\hline Crude protein $\%$ & $81.81^{\mathrm{a}}$ & $79.09^{\mathrm{b}}$ & 0.21 & 0.000 \\
\hline Ether extract \% & $7.16^{\mathrm{b}}$ & $8.47^{\mathrm{a}}$ & 0.30 & 0.005 \\
\hline \multicolumn{5}{|l|}{ Breast Meat } \\
\hline \multicolumn{5}{|c|}{ Sex } \\
\hline & Male & Female & SEM & P-value \\
\hline Crude protein $\%$ & $86.86^{\mathrm{a}}$ & $85.09^{\mathrm{b}}$ & 0.23 & 0.000 \\
\hline Ether extract \% & $1.37^{\mathrm{b}}$ & $2.52^{\mathrm{a}}$ & 0.11 & 0.000 \\
\hline
\end{tabular}

a,b Mean with different superscripts in a row differ significantly $(\mathrm{P} \leq 0.05) ; \mathrm{N}=6$ ( 3 male and 3 female per system)

Table 4: Effect of rearing systems on chemical composition of thigh and breast meat of Hansli $\times$ CSML birds

\begin{tabular}{|c|c|c|c|c|}
\hline \multirow{3}{*}{ Attributes } & \multicolumn{4}{|c|}{ Thigh Meat } \\
\hline & \multicolumn{2}{|c|}{ Rearing system } & \multirow[b]{2}{*}{ SEM } & \multirow[b]{2}{*}{ P-value } \\
\hline & Intensive & Semi-intensive & & \\
\hline Crude protein $\%$ & 80.01 & 80.90 & & 0.327 \\
\hline Ether extract \% & $8.41^{\mathrm{a}}$ & $7.22^{\mathrm{b}}$ & & 0.039 \\
\hline \multicolumn{5}{|c|}{ Breast Meat } \\
\hline \multicolumn{5}{|c|}{ Rearing system } \\
\hline & Intensive & Semi-intensive & SEM & P-value \\
\hline Crude protein $\%$ & 85.47 & 86.47 & 0.40 & 0.107 \\
\hline Ether extract \% & 2.16 & 1.73 & 0.26 & 0.278 \\
\hline
\end{tabular}

a,b Mean with different superscripts in a row differ significantly $(\mathrm{P} \leq 0.05) ; \mathrm{N}=6$ (3 male and 3 female per system).

In the present investigation, no significant difference $(\mathrm{P}>0.05)$ was observed in the crude protein $\%$ of the thigh and breast meat of Hansli $\times$ CSML under intensive and semi-intensive system. Higher ether extract \% was observed in thigh and breast meat of birds under intensive system as compared to semi-intensive system, with significant difference $(\mathrm{P} \leq 0.05)$ only in thigh meat. Also, the thigh meat had higher fat $\%$ and lower protein $\%$ than breast meat under both the systems. The present findings were in agreement with the findings reported by various workers (Fanatico et al., 2007; Bartlett et al., 2015; Dou et al., 2009) indicating that the rearing systems did not significantly affect the protein and fat content in thigh and breast meat of birds. Conversely, many workers (Bogosavljevic-Boskovic et al., 2011 and Ristić, 2003) reported that rearing systems had a significant effect on protein and fat content in the above mentioned meat as access to the outdoor environmental conditions (fresh air and sunlight) also resulted in differences in terms of the structural manifestations of tissues and organs, as well as in terms of the biochemical processes involved in the metabolism due to increased physical activity that could reduce the fat content of meat.

In the present study, it was observed that the thigh and breast meat of female birds had significantly higher $(\mathrm{P} \leq 0.05)$ fat and lower protein content as compared to males. These findings were in agreement with a number of researchers (Sanz et al., 1999; Haro, 2005; Tumova and Teimouri, 2010) who have stressed the effect of sex on the protein and fat content of meat. They observed a higher fat content in female birds as compared to males was associated with metabolic differences, higher competitiveness among males, difference in fat deposition capacity, different nutritional requirements and a higher hormonal effect in females.

\section{CONCLUSION}

Rearing system and sex has a significant influence on live body weight and carcass traits of birds. As the birds under intensive system attained a higher live body weight than that of birds under semi-intensive system, the eviscerated, dressed, primal cut parts and giblet weight were higher for birds under intensive system. The higher drumstick, thigh, neck and wings yield \% of birds under semi-intensive system may be due to better muscle mass growth, owing to their scavenging activities in pasture. The live weight and carcass traits of male birds were significantly higher than that of female birds. Sex has a significant effect on the chemical composition of meat with female birds having a higher fat deposition capacity as compared to males. The effect of rearing system although non-significant showed 
that birds under semi-intensive system had a leaner meat (high protein and low fat contents) in comparison to birds under intensive system. Therefore, rearing birds under semi-intensive system could have a nutritional and economic advantage over intensive system in terms of meat quality and is better accepted by consumers.

\section{ACKNOWLEDGMENTS}

The authors are grateful to the ICAR-DPR, Hyderabad, India for providing the facilities to carry out this research work.

\section{REFERENCES}

A.O.A.C. 1990 . Official Methods of analysis. $12^{\text {th }}$ ed. Association of official Analytical Chemist., Arlington, VA.USA

A.O.A.C. 1995. Official Method of Analysis. $16^{\text {th }}$ Ed. Association of Official Analytical Chemists, P.O. Box 540, Benjamin Franklin Station, Washington D.C. 20044.

Bartlett, J.R., Liles, K.M. and Beckford, R.C. 2015. Comparing the effects of conventional and pastured poultry production systems on broiler performance and meat quality. J. Agric. Life Sci., 2(1): 29-36.

Bogosavljević-Bošković, S., Mitrović, S., Dosković, V., Rakonjac, S. and Kurćubić, V. 2011. Carcass composition and chemical characteristics of meat from broiler chickens reared under intensive and semi intensive systems. Biotechnol. Anim. Husb., 27(4): 1595-1603.

Castellini, C., Muginai, C., Dal Bosco, A. 2002. Effect of organic production system on broiler carcass and meat quality. Meat Sci., 60: 219-225.

Doley, S., Barua, N., Kalita, N. and Gupta, J.J. 2009. Studied performance of indigeneous chicken of North Eastern region of India under different rearing system. Indian J. Poult. Sci., 44(2): 249-252.

Dou, T.C., Shi, S.R., Sun, H.J. and Wang, K.H. 2009. Growth rate, carcass traits and meat quality of slow growing chicken according to three raising systems. Anim. Sci. Pap. Rep., 27(4): 361-369.

Fanatico, A.C., Pillai, P.B., Cavitt. L.C., Owens, C.M. and Emmert, J.L. 2005. Evaluation of slow growing broiler genotypes grown with and without outdoor access: growth performance and carcass yield. Poult. Sci., 84: 1321-1327.

Fanatico, A.C., Pillai, P.B., Emmert, J.L. and Owens, C.M. 2007. Meat quality of slow and fast growing chicken genotypes fed low nutrient or standard diets and raised indoors or with outdoor access. Poult. Sci., 86(10): 2245- 2255.
Gordon, S.H. and Charles, D.R. 2002. Niche and Organic Chicken Products. Nottingham University Press, Nottingham, UK.

Haro, C.V. 2005. Interaction between dietary polyunsaturated fatty acids and vitamin $E$ in body lipid composition and -tocopherol content of broiler chickens. Ph.D thesis. Universitat Autonoma de Barcelona, Spain, pp. 140.

Kalio, G.A. and Okafor, B.B. 2012. Response of Broilers to Two Management Systems of Housing in Etche Local Government Area of Rivers State, Nigeria. Asian J. Agric. Rural Dev., 2(2): 184-188.

Kaya, S. and Yildirim, H. 2018. Effects of a semi-intensive raising system on growth performance, carcass traits and meat quality of broiler chicks. Indian J. Anim. Res., 52(2): 309-313.

Kuźniacka, J., Adamski, M., Czarnecki, R. and Banaszak, M. 2014. Results of rearing broiler chickens under various systems. J. Agric. Sci., 6(4): 19-25.

Melo, J., Mallo, G., Willar, E., Miquel, M.C., Cappelleti, C. and Fernandez, P. 1996. Evaluation of two poultry commercial strains in three feeding regimes at two slaughter ages. In XXth World Poultry Congress, New Delhi, India, pp. 80.

Ozkan, S., Settar, P. and Yalcin, S. 1997. Effects of seasonal ambient temperature on yields of naked neck broilers $(\mathrm{Na} / \mathrm{na})$ and their normally feathered (na/na) halfsibs. Poultry Meat Quality. In Processing XIII. European Symposium Quality of Poultry Meat, Poznan, Poland. Session M-1: 49-52.

Ristić, M. 2003. Fleischqualität von broiler aus der ökologischen produktion. Biotechnol. Anim. Husb., 19(5-6): 335-343.

Sanka, Y.D. and Mbaga, S.H. 2014. Evaluation of Tanzanian local chicken reared under intensive and semi intensive systems: I. Growth performance and carcass characteristics. Livest. Res. Rural Dev., 26(7): 1-7.

Sanz, M., Flore, A., Perez de Ayala, P. and Lopezborte, C.J. 1999. Effect of Fatty Acid Saturation in Broiler Diets on Abdominal Fat and Breast Muscle Fatty Acid Composition and Susceptibility to Lipid Oxidation. Poult. Sci., 78: 378382.

Suchy, P., Jelinek, P., Strakova, E. and Hucl, J. 2002. Chemical composition of muscles of hybrid broiler chickens during prolonged feeding. Czech J. Anim. Sci., 47: 511-512.

Tumova, E. and Teimouri, A. 2010. Fat Deposition in the broiler chicken: a rewiew. Sci. Agric. Bohem., 41(2): 121-128. 
